SB 983

W2 A5

1915

Copy 1

\title{
State of Washington
}

\section{Horticultural Laws}

OF THE

\section{State of Washington}

Chapter 166, Session Laws 1915

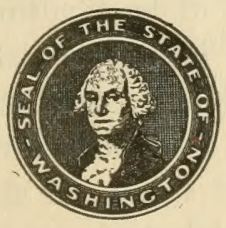

OLYMPIA.

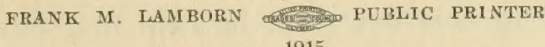




\section{CHAPTER 166.}

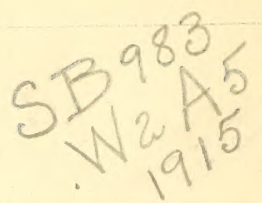

AN ACT relating to horticulture and horticultural plants and products and the protection thereof, prescribing certain rules of evidence, requiring certain contracts to be in writing, authorizing the levy and collection of taxes for horticultural purposes, providing for the enforcement of the provisions hereof by writs of mandate and injunction, authorizing counties and municipalities to aid in the enforcement hereof, validating certain expenditures heretofore made for the protection of horticultural interests, providing penalties for violations of this act and methods of collecting the cost of enforcing the same in certain cases, repealing sections 3075, 3079, 3080,3083 to 3110 inclusive; $3113,3115,3116,3117,3119,3120$, 3122 to 3127 inclusive; 3131 and 3134 to 3139 inclusive of Remington and Ballinger's Annotated Codes and Statutes of Washington, and declaring this act shall take effect immediately.

Be it enacted by the Legislature of the State of Washington:

Section 1. That the term "Commissioner" whenever used in this act shall be held and construed to mean the commissioner of agriculture of the State of Washington, and the term "assistant commissioner" and "assistant" shall be held and construed to mean the assistant commissioner of agriculture for the division of horticulture; the term "horticultural inspector" and the term "inspector" wherever used in this act shall be held and construed to mean an inspector of the department of agriculture, assigned to the division of horticulture; the term "nursery stock" wherever used in this act shall be held and construed to mean and include fruit trees, fruit tree stock, nut trees, grape vines, fruit bushes, rose bushes, rose stock, forest and ornamental trees and shrubs (both deciduous and evergreen), florists' stock, and cuttings, scions and seedlings of fruit or ornamental trees or shrubs, and all other fruit bearing plants and parts thereof and plant products for propagation or planting; the term "infect" and its derivatives "infecting," "infected" and "infection," wherever used in this act shall be held and construed to mean and include being affected by or infested with the dis-

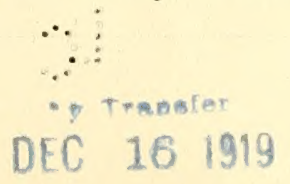


ease or insect pests to which horticultural plants and products are subject and which are required to be guarded against, controlled, cured, removed, and eradicated as in this act provided; the term "disinfect" and its derivatives shall be held and construed to mean and include the cure, removal or eradication of such diseases or pests by cutting and destroying the infected parts, or the application of fungicides or insecticides specified in this act or such other effective solutions or emulsions as may be discovered by science and specified and described in the bulletins issued by the commissioner of agriculture, and the term "person" wherever used in this act, shall be held and construed to mean and include individuals, partnerships, associations, joint stock companies and corporations.

SEc. 2. The commissioner of agriculture shall have the power and it shall be his duty:

(a) To exercise a general supervisory and directory control over the horticultural interests of the state:

(b) To arrange for and hold meetings for the discussion and dissemination of information as to horticultural subjects and for the demonstration of methods of preventing diseases of and pests injurious to horticultural plants, fruits and vegetables, and of curing and removing the same:

(c) To publish and distribute circulars and reports upon horticultural subjects, the pests affecting and the diseases of fruit trees, vines or bushes, ornamental trees or shrubbery, horticultural plants, fruits, vegetables and nursery stock, and the means and methods of controlling, curing, removing, eradicating and disinfecting for such diseases and pests:

(d) To issue licenses to nurserymen and dealers in nursery stock and their agents, salesmen and solicitors and revoke the same for violations of or failure to comply with this act, and to keep in his office a record of all licenses issued, showing the character of the license, name and address of the holder, the date of issue and the date of expiration or revocation: 
(e) To furnish to the board of county commissioners of each county, annually, on or before September 1, an estimate of the expenses for the ensuing year of inspecting and disinfecting orchards, vineyard, berry farms, vegetable farms and nurseries, and packing houses, warehouses, store-rooms, depots, docks and other places where fruits, vegetables or nursery stock are grown, packed, stored, shipped or held for shipment or delivery or offered for sale within said county;

(f) To appoint inspectors to enforce and carry out the provisions of this act, which inspectors may be of two classes, inspectors at large and local inspectors: Provided, That not more than twenty inspectors at large shall be appointed.

(g) The commissioner may also in his discretion appoint any officer or member of any local fruit protective association to act as inspector, vested with power only to enter premises and inspect orchards and report to the inspector-at-large. Such inspectors shall receive no compensation for services and shall not be required to take the regular examination required of inspectors-at-large and local inspectors.

(h) To make, adopt, issue and publish from time to time and enforce general rules and regulations governing the grading and packing of apples, and other fruits.

The commissioner of agriculture, and under his direction and control the assistant commissioner and the horticultural inspectors, shall have the power and it shall be their duty:

(a) To enforce the provisions of this act and all laws relating to horticultural interests :

(b) To inspect orchards, vineyards, berry farms, vegetable farms, nurseries, fruit trees, vines or bushes, ornamental trees or shrubbery, horticultural plants, fruits, vegetables, nursery stock and horticultural supplies, and packing houses, dry houses, warehouses, store-rooms, depots, docks, cars, vessels and other places where fruits, vegetables or nursery stock are packed, stored, shipped or held for shipment or delivery or offered for sale, and other 
property liable to be infected with any disease or pest injurious to horticulture, and to require the disinfection of all such property and premises found to be infected and for that purpose shall have free access to such property and premises at all times.

(c) To inspect and examine orchards, vineyards, nurseries, berry farms, vegetable farms, fruits, vegetables, nursery stock and all other horticultural plants and products, at the request of the owner thereof for the purpose of discovering the existence of any disease or pest, and to report to the applicant the result of such investigation and prescribe proper remedies;

(d) To disinfect orchards, vineyards, berry farms, nurseries, fruit trees, vines and bushes, ornamental trees and shrubbery, horticultural plants, fruits, vegetables and nursery stock, and packing houses, dry houses, warehouses, store-rooms, depots, docks, cars, vessels and other places where nursery stock, fruits or vegetables are packed, stored or shipped or held for shipment or delivery or offered for sale, in case the owner or person having the same in charge shall neglect or refuse so to do, after notice; and in case any infected fruit trees, vines or bushes, ornamental trees or shrubbery, horticultural plants, fruits, vegetables or nursery stock cannot be successfully disinfected to condemn and destroy the same or cause the same to be destroyed;

(e) To require all partially infected fruit, vegetable and nursery stock shipments to be sorted and repacked and, in case the owner or person having charge of the same shall neglect or refuse so to do after notice, to condemn and destroy the same;

(f) To issue certificates of inspection to licensed nurserymen and dealers in nursery stock, on stock inspected and approved.

SEc. 3. Inspectors-at-large may be assigned to duty in one or more counties and transferred from one county to another in the discretion of the commissioner, and their salaries, compensation and actual and necessary traveling 
expenses shall be paid by warrants drawn upon the state treasurer by the state auditor upon vouchers signed and verified under oath by such inspectors and countersigned by the commissioner or the assistant commissioner. In addition to inspectors-at-large the commissioner shall, whenever the board of county commissioners of any county by resolution request it, appoint such number of local inspectors and for such length of time as such resolution shall specify and assign them to duty in such county. The salaries, not to exceed four dollars per day, and actual and necessary traveling expenses, within the county, of all local inspectors shall be paid out of the current expense fund of their respective counties upon vouchers signed and verified under oath by such inspectors and approved by the commissioner or the assistant commissioner, and the county auditor shall issue warrants therefor upon the said county fund. All local inspectors shall be under the direction and control of the commissioner of agriculture and the assistant commisisoner. In case any inspector is dismissed from the service or transferred to another place, or to other duties, any qualified inspector or officer of the agricultural department may continue or complete any work or perform any duty initiated by such dismissed or transferred officer.

Sec. 4. It shall be the duty of every person owning, leasing or occupying any land or premises on which there is or shall be growing, grown or situate any nursery stock, fruit trees, vines or bushes, shade trees, ornamental trees or shrubbery, or any horticultural plants, and of the owner or lessee of any such nursery stock, trees, fruit trees, vines, bushes, shrubbery or plants growing or situate on premises leased or occupied by him, and of the owner of any such nursery stock, trees, fruit trees, vines, bushes, shrubbery or plants growing, situate or being at any place within the State of Washington, for sale or delivery, and of every grower, shipper, commission merchant, consignee, dealer in and person in charge of any nursery stock, fruit or vegetables about to be shipped, or shipped, or held for 
delivery or offered for sale, to take and use sufficient methods and means for the prevention of infection by all pests and diseases to which such nursery stock, trees, fruit trees, vines, bushes, shrubbery, plants, fruits or vegetables may be subject, and to keep the same free from disease and pests, and, in event it is found that any such nursery stock, trees, fruit trees, vines, bushes, shrubbery, plants, fruits or vegetables are infected with any disease or pest, to promptly take and use effective means to control, cure, remove, eradicate and disinfect for the same, and in case such nursery stock, trees, fruit trees, vines, bushes, shrubbery, plants, fruits or vegetables cannot be successfully disinfected, to promptly destroy the same, and it shall be the duty of every owner and of the lessee of any premises upon which there are growing any infected fruit, fruit trees, shade or ornamental trees, vines or bushes, to thoroughly spray the same with a proper solution or emulsion or otherwise disinfect the same for the control, cure or removal of such infection.

SEC. 5. The pests injurious to and diseases of nursery stock, fruit trees, shade trees, ornamental trees and shrubbery, horticultural plants, fruit and vegetables to be guarded against, controlled, treated, removed, eradicated and disinfected for, as in the next preceding section provided, shall be all bacterial diseases, including fire blight of apple, pear and quince, crown gall or root gall, and hairy root; all fungus diseases, including black spot canker, pear scab, apple scab, apple powdery mildew, peach leaf curl, peach mildew, brown rot of peach, cherry and prune, chestnut blight, potato wart, powdery scab of potato and peach twig blight; all insect pests, including chewing insects, such as bud moth, peach twig borer, caterpillars, pear slug, flat-headed borer, round-headed borer, imported cabbage worm, potato tuber moth, potato nematode or eel worm, Mediterranean fruit fly, lesser apple worm, tussock moth, gypsy moth, brown tail moth, coddling moth, and the larva of any thereof, and sucking insects, such as San Jose scale, scurfy scale, oyster shell 
bark louse, aphids, pear leaf blistermites and red spider; and such other bacterial and fungus diseases and insect pests as may be identified by science and specified and described as injurious to horticulture in the circulars to be issued from time to time by the commissioner of agriculture.

The methods and means required to be used for the prevention, control, removal, eradication and cure of the diseases and pests above specified, shall be as follows: For bacterial diseases, eradication by the removal and destruction of the infected plant or part thereof, care being taken to disinfect all tools used in such removal to prevent the spread of the infection or by any other methods that shall have been approved by the insecticide and fungicide board; for fungus diseases, control or cure by spraying with effective fungicides, such as bordeaux solution, lime-sulphur solution, sulphide of iron or other effective fungicides; for chewing insect pests, control or removal by spraying with effective insecticides, such as arsenate of lead solution and arsenite or zinc solution; for sucking insect pests, control or removal by spraying with effective insecticides such as lime-sulphur solution, crude oil emulsion, tobacco solution, distillate oil emulsion, kerosene emulsion, soap solution, and sulphur solution, or combinations thereof; and for fungus and insect pests, control, cure or removal by spraying with such other effective solutions and emulsions as may be discovered by science and specified and described in the circulars issued by the commissioner of agriculture.

SEC. 6. There is hereby created a board to be known as the state insecticide and fungicide board, which board shall consist of the commissioner of agriculture or the assistant commissioner, the director of the agricultural experiment station at Pullman and three members of the agricultural experiment station to be appointed by the director, one of whom shall be an entomologist, one a plant pathologist and one a chemist. It shall be the duty of the said board to analyze and report upon any insecticides and fungicides offered for sale to be used in the control and re- 
moval of insect pests and fungus and bacterial diseases to which horticultural plants are subject. It shall be the duty of all horticultural inspectors to from time to time procure and submit to such board samples of such insecticides and fungicides offered for sale.

SEc. \%. It shall be unlawful for any person to offer for sale in the State of Washington any horticultural insecticide or fungicide which is adulterated or misbranded within the meaning of this act. The term "insecticide" as used in this act shall include any substance or mixture of substances intended to be used for preventing, destroying, repelling, or mitigating any insects which may infest vegetation. The term "Paris green" as used in this act shall include the product sold in commerce as Paris green and chemically known as the aceto-arsenite of copper. The term "lead arsenate" as used in this act shall include the product or products sold in commerce as lead arsenate and consisting chemically of products derived from arsenic acid (H3As04) by replacing one or more hydrogen atoms by lead. That the term "fungicide" as used in this act shall include any substance or mixture of substances intended to be used for preventing, destroying, repelling, or mitigating any and all fungi that may infest vegetation or be present in any environment whatsoever.

SEc. 8. That for the purpose of this act an article shall be deemed to be adulterated-

In the case of Paris green: First, if it does not contain at least fifty per centum of arsenious oxide; second, if it contains arsenic in water-soluble form equivalent to more than three and one-half per centum of arsenious oxide; third, if any substance has been mixed and packed with it so as to reduce or lower or 'injuriously affect its quality or strength.

In the case of lead arsenate: First, if it contains more than fifty per centum of water; second, if it contains total arsenic equivalent to less than twelve and one-half per centum of arsenic oxid (As205) ; third, if it contains arsenic in water-soluble form equivalent to more than seven- 
ty-five one hundredths per centum or arsenic oxid (As205); fourth, if any substances have been mixed and packed with it so as to reduce, lower, or injuriously affect its quality or strength: Provided, however, That extra water may be added to lead arsenate (as described in this paragraph) if the resulting mixture is labeled lead arsenate and water, the percentage of extra water being plainly and correctly stated on the label.

In the case of insecticides or fungicides, other than Paris green and lead arsenate: First, if its strength or purity fall below the professed standard or quality under which it is sold; second, if any substance has been substituted wholly or in part for the article; third, if any valuable constituent of the article has been wholly or in part abstracted; fourth, if it is intended for use on vegetation and shall contain any substance or substances which, although preventing, destroying, repelling, or mitigating insects, shall be injurious to such vegetation when used.

That the term "misbranded" as used herein shall apply to all insecticides, Paris green, lead arsenates, or fungicides, or articles which enter into the composition of insecticides or fungicides, the package or label of which shall bear any statement, design, or device regarding such article or the ingredients or substances contained therein which shall be false or misleading in any particular, and to all insecticides, Paris greens, lead arsenates, or fungicides which are falsely branded as to the state, territory, or country in which they are manufactured or produced.

That for the purpose of this act an article shall be deemed to be misbranded-

In the case of insecticides, Paris greens, lead arsenates, and fungicides: First, if it be an imitation or offered for sale under the name of another article; second, if it be labeled or branded so as to deceive or mislead the purchaser, or if the contents of the package as originally put up shall have been removed in whole or in part and other contents shall have been placed in such package; third, if in pack- 
age form, and the contents are stated in terms of weight or measure, they are not plainly and correctly stated on the outside of the package.

In the case of insecticides (other than Paris greens and lead arsenates) and fungicides: First, if it contains arsenic in any of its combinations or in the elemental form and the total amount or arsenic present (expressed as per centum of metallic arsenic) is not stated on the label; second, if it contains arsenic in any of its combinations or in the elemental form and the amount of arsenic in watersoluble forms (expressed as per centum of metallic arsenic) is not stated on the label; third, if it consists partially or completely of an inert substance or substances which do not prevent, destroy, repel, or mitigate insects or fungi and does not have the names and percentage amounts of each and every one of such inert ingredients plainly and correctly stated on the label: Provided, however, That in lieu of naming and stating the percentage amount of each and every inert ingredient the producer may at his discretion state plainly upon the label the correct names and percentage amounts of each and every ingredient of the insecticide or fungicide having insecticidal or fungicidal properties, and make no mention of the inert ingredents, except in so far as to state the total percentage of inert ingredients present.

SEC. 9. The commissioner of agriculture, the assistant commissioner and all horticultural inspectors are authorized and empowered to at any time enter upon any premises where any nursery, orchard, vineyard, berry farm or vegetable farm is situate or whereon any nursery stock, fruit trees, shade trees, ornamental trees or shrubbery or horticultural plants are growing, or upon any premises or into any building, packing house, dry house, warehouses, store-room, depot, dock, car, vessel, or other place wherein any nursery stock, fruits, vegetables, or horticultural products are situate, being prepared or packed for shipment, stored, shipped, held for shipment or for delivery upon any shipment or sale, or offered for sale for the pur- 
pose of examining and inspecting such premises or property to ascertain whether the same or any thereof are infected, and it shall be unlawful for any person to hinder or prevent or to attempt to hinder or prevent any such officer from entering such premises or inspecting such premises or property or performing any duty required by this act.

SEC. 10. In case the officer making the inspection provided for in the preceding section shall find that the premises or property inspected is infected, he shall condemn the same and serve upon the owner or upon the person having possession or charge of said premises or of said property a notice in writing that the same is condemned and ordering the disinfection of any and all thereof which is capable of disinfection and the destruction of such property as is incapable of disinfection, which notice shall describe the premises or property ordered to be disinfected or destroyed with reasonable certainty and shall specify the time within which the same shall be so disinfected or destroyed; and shall give notice that unless the premises or property ordered disinfected or destroyed is disinfected or destroyed as directed, in the manner and within the time specified in said notice, the same will be done by the officer giving the notice and the expense thereof charged against the premises and the owner of said premises or property. In case said premises or property is in the possession or charge of any person upon whom service can be made, the officer making the inspection shall serve a copy of such notice upon such person and, in case the premises or property is in possession or charge of any other person than the owner thereof, or service cannot be had upon any person in possession or charge thereof, the officer shall serve said notice upon the owner of said premises or property by mailing or telegraphing him a copy thereof, if his name or postoffice address are known to the officer or can with reasonable diligence be ascertained. In case personal service of said notice cannot be had upon any person in possession or charge of said premises or property and the 
name and address of the owner of such premises or property are not known and cannot with reasonable diligence be ascertained, said notice shall be served by posting the same in a conspicuous place upon the premises where the property to be disinfected or destroyed is situated, as the case may be. In case the name and postoffice address of the owner are not known and cannot with reasonable diligence be ascertained and in the absence of fraud and gross neglect, service of such notice upon the person in possession or charge of said premises or property shall be construed to be substituted personal service upon the owner, and, in case service of such notice upon a person in possession or charge of such premises or property cannot be had and the name and post office address of the owner is not known and cannot with reasonable diligence be ascertained and in the absence of fraud and gross neglect, such posting of the notice upon the premises shall be construed to be constructive personal service upon the owner of such premises or property. Upon the giving of such notice as hereinabove provided it shall become and be the duty of the owner and person having possession or charge of the premises or property described in the notice to, within the time specified in said notice, disinfect said premises or disinfect or destroy said property, as the case may be: Provided, That in the case of nursery stock, fruit or vegetables about to be shipped or any shipment thereof, or which is offered for sale, or held for the purpose of delivery upon any shipment or sale thereof, if the officer making the inspection shall find that only a part thereof is so affected that it cannot be successfully disinfected, he shall state in such notice that the owner or person in charge thereof has the privilege of separating the same into two or more of the following classes, to-wit, such as does not need disinfection, such as can be successfully disinfected, and such as cannot be successfully disinfected, and in such cases it shall be the duty of the owner and person in charge of such property to, within the time specified in said notice, disinfect such nursery stock, fruit or vegetables as can be successfully 
disinfected and destroy such as cannot be successfully disinfected: And provided, further, That in the case of fruit or vegetables that cannot be successfully disinfected the inspector may grant the owner or person in charge thereof the privilege of manufacturing the same into by-products or of shipping the same to a by-product factory and issue a permit in writing so to do, and in such case it shall be unlawful for the person receiving such permit to sell or dispose of such infected fruit without having first manufactured the same into a by-product or shipped the same to a by-product factory, or to divert any such shipment when made, and it shall be unlawful for the consignee of any fruit or vegetables shipped to a by-product factory, to sell or dispose of the same without first manufacturing it into a by-product. It shall be unlawful for any person to ship, deliver, sell, barter, give away or otherwise dispose of or part with the possession of any nursery stock, fruit or vegetable which has been found infected and condemned until all of the requirements of said notice and order have been complied with, and permission given in writing so to do by an inspector.

SEC. 11. In case the owner or person in charge of any premises or property required to be disinfected or destroyed as in the previous section provided, shall fail or neglect to comply with the notice within the time specified therein, the officer giving the notice shall have the right and it shall be his duty to enter upon the premises to be disinfected or where the personal property required to be disinfected or destroyed is situated and perform the acts required in such notice, or cause the same to be performed at the cost and expense of the owner of such premises or property as the case may be. The officer shall keep an accurate account of such cost and expense and the same shall be a lien upon the premises or personal property so disinfected, which lien may be enforced by the methods hereinafter provided. The liens in this section provided for shall in the case of personal property have precedence over all other liens. 
SEC. 12. The officer disinfecting any personal property may, in case the owner or person in charge shall not pay such cost and expense, impound and sell such property to enforce the lien of the state and collect such cost and expense. The officer impounding personal property as above provided shall give notice in writing that the property is impounded which notice shall describe the property with reasonable certainty, state where the same is impounded, specify the amount of costs and expenses charged against it and state that unless the charges are paid within a time specified in said notice the property will be sold to satisfy the charges against it and the transportation and storage charges accrued, if any, and the cost of making the sale. The officer giving such notice shall post it in a conspicuous place upon the premises where such property is impounded and serve the same upon the owner or upon the person in possession or charge of such impounded property in like manner with like effect as hereinabove in this act provided for service of notice to disinfect. The time within which a sale shall be had after the giving of the notice shall not be less than ten days: Provided, That in the case of perishable fruits or vegetables, the same may be had immediately. Sales may be either at public auction or private sale as in the sound discretion of the officer may be for the best interest of the state and the owner of the property to be sold. The proceeds of any such sale shall be applied first to the payment of the cost of making the sale, second to the payment of the cost and expense of disinfection and third to the payment of accrued transportation and storage charges, if any, and the balance, if any, shall be paid the owner or person in charge of the property sold, upon demand. In case the proceeds of such sale be not sufficient to pay the cost of making the sale, and the cost and expense of disinfection, the deficiency may be recovered from the owner of the property disinfected in an action at law in the name of the state on the relation of the commissioner of agriculture, and the prosecuting attorney of the county where the property was disinfected shall, 
when directed so to do by the attorney general, bring such action for the recovery of such deficiency. The officer making such sale shall make and keep a full and detailed record of all acts done by him with reference to such propcrty, stating the name of the owner or reputed owner of such property when known, the location thereof, the date of inspection, the facts found upon inspection, the date and manner of giving the notice to disinfect, the failure of the owner or person in charge to disinfect, the disinfection by or under the direction of the officer, the cost and expense thereof in detail, the date and manner of giving the notice of impounding and sale, the date, place and manner of sale, the name of the person to whom the property was sold, the amount of the proceeds of the same and the disposition made thereof, which record shall be signed by the officer making the same. Upon demand of the owner or person in charge of such property, the officer making the sale shall furnish him with a copy of such record verified under oath, and shall tender him the balance of said proceeds. If no demand is made upon the officer making such sale within thirty days from the date of sale, or in case the balance of said proceeds is not accepted when tendered, the officer shall file a verified copy of such record with and remit the balance of the proceeds of such sale to the commissioner of agriculture, who shall retain the same for a period of six months subject to the order of the owner of the property sold, and if at the end of six months such proceeds be not claimed and accepted by the owner or his order, the same shall be turned into the state treasury. The record required to be kept as hereinabove provided and the verified copy thereof shall be prima facie proof of the truth of the facts therein stated in any court in any action or proceeding where proof of such facts is competent.

SEc. 13. It shall be the duty of the board of county commissioners of each county at the time of making the regular annual tax levy in each year to include a tax upon the taxable property of such county in such an 
amount as they shall find will produce funds sufficient to meet the expense of inspecting and disinfecting orchards, vineyards, berry farms, vegetable farms, nurseries, fruit trees, vines or bushes, ornamental trees or shrubbery, horticultural plants, and packing houses, warehouses, dry houses, store-rooms, depots, docks and other places where fruits, vegetables or nursery stock are packed, stored, shipped or held for shipment or delivery or offered for sale within said county, which shall be inspected or disinfected by or under the direction of an inspector, which tax shall be known as the "horticultural tax." In estimating the amount to be levied for such horticultural tax, the county commissioners shall take into consideration the expense of inspecting and disinfecting the above mentioned property within said county for the ensuing year and the amount that will be collected from levies on property disinfected as in this act provided. The horticultural tax shall be levied and collected in the same manner as other general taxes and when collected shall be placed in the current expense fund of said county. Until the collection by any county of the taxes to be levied under the provisions of this section at the next annual tax levy after the taking effect of this act, the county commissioners of such county are authorized and empowered to cause to be paid, by warrants drawn upon the current expense fund of such county, all expenses for inspecting and disinfecting premises or property within said county properly chargeable to such county under the provisions of this act, and all expenditures made from and warrants drawn upon the current expense fund of any county by order of the board of county commissioners of such county, subsequent to the repeal of section 3133 of Remington and Ballinger's Annotated Codes and Statutes of Washington and prior to the passage of this act for the purpose of paying the cost and expense of inspecting or disinfecting premises or property in such county as provided in this act, are hereby validated.

SEC. 14. The cost and expense of disinfecting any nursery, orchard, berry farm, vineyard or vegetable farm, 
or any nursery stock, fruit trees, vines or bushes, shade trees, ornamental trees or shrubbery or horticultural plants growing on any premises, or any packing houses, warehouse, dry houses, store-rooms, depots, or other premises where nursery stock, fruits, vegetables or horticultural products are stored, situated or being prepared or packed for shipment or offered for sale or held for the purpose of delivery upon any shipment or sale, may be recovered as in this section provided. The officer disinfecting any premises or property growing upon any premises or causing the same to be disinfected as in this act provided shall make and keep a full and detailed record of all acts done by him with reference to such property or premises, stating the legal description of premises upon which property disinfected was growing, the name of the owner or reputed owner, the date of inspection, the facts found upon inspection, the date and manner of giving of notice to disinfect, the failure of the owner or person in charge to disinfect, the disinfection by or under the direction of the officer, the cost and expense thereof in detail, which record shall be signed by the officer making the same. In case the cost and expense of disinfecting any premises, or the property growing thereon, are not paid within five days after the completion of the work of disinfecting, the officer making such record shall make and file with the county auditor of the county where such premises are situated two verified copies of the record of his acts with reference to said premises and the charge against the same, and shall also file a claim of lien against said premises for the amount of such charges and expenses, which said claim shall refer to said record. Upon the filing of such verified record and claim of lien the county auditor shall record the said claim of lien as other lien claims are recorded. The county auditor shall also, at the time when said record and claim are filed, forthwith issue proper warrants in payment for labor of men employed in the work and fix a day for a hearing upon the report before the board of county commissioners, which date shall not 
be less than twenty days from the date of said filing and shall prepare a notice of the filing of such record and claim and of the date of hearing upon the same and in all proceedings the county shall be deemed substituted to all the rights of laborers paid as herein provided. Said notice shall be directed to the owner, or reputed owner, and shall give notice of the filing of said record and claim and of the amount thereof and shall also give notice of the time and place when and where the board of county commissioners will hear and determine the same. The county auditor shall deliver said notice, together with a copy thereof, to the sheriff of the county in which said claim is filed and the sheriff shall make service thereof in like manner and with like effect as herein provided for the service of notice to disinfect and shall make return of such service upon the original notice and file the same with the county auditor before the time of hearing of the same, and he shall also certify with said return the amount of his fees for such service, which shall be the same as is provided for service of summons in civil proceedings. In case the amount of said claim, together with the amount of sheriff's fees and auditor's fees, which shall be the same as is charged for the filing and recording of other liens, is paid to the county treasurer on or before the date of said hearing before said board of county commissioners, the auditor shall, upon the presentation to him of a duplicate receipt of said treasurer for the amount above specified, cancel the said lien in the records of his office and notify the board of county commissioners of his action in the premises. The county treasurer shall disburse the fund received by him as above provided to the parties entitled to receive the same according to the record as shown in the office of the county auditor. In case the amount of said claim, together with costs as above provided, is not paid at or before the time of the hearing before the board of county commissioners, the county auditor shall present a verified copy of said claim and record to the said board, which shall proceed with the hearing upon the same and shall, if offered, hear sworn testimony con- 
cerning the matter set forth in said record and claim. The record required to be kept by the officer disinfecting, as hereinabove provided, and the verified copy thereof filed with the county auditor, shall be prima facie proof of the facts therein stated in any proceedings before the board of county commissioners and in any court in any action or proceding where proof of such facts is competent or the validity of such charges or any tax levied therefor is questioned. After the hearing as herein provided for, the county commissioners shall make an order fixing the amount of such claim and costs and shall order the amount so fixed paid out of the current expense fund of said county, and the auditor shall draw warrants for the payment of such claim as fixed by the county commissioners. The said order of said board fixing the amount of said claim and costs shall be recorded by the county auditor as are other lien claims and shall stand as a lien in favor of said county agrainst the premises therein described until cancelled as herein provided. In case the amount of said lien, together with interest thereon at the rate of six per cent per annum from the date of said order of said board of county commissioners, is paid to the county treasurer of said county on or before the first Monday in October following the date of said order and a duplicate receipt therefor of said treasurer is presented to said county auditor, the county auditor shall cancel said claim of lien in the records of his office. Payment to the county treasurer as above set forth shall be made by presenting to said treasurer a statement over the signature of the county auditor of the amount due upon said claim together with the amount of money shown by said statement to be due. Upon said payment being so made the treasurer shall stamp said statement as paid, showing the date of said payment, and shall file said statement so stamped in the records of his office; he shall also issue a duplicate receipt for said payment and shall deliver one of said receipts to the party making payment and immediately transmit one of said receipts to the county auditor. In case the amount of said claim and 
costs, together with interest at the rate of six per cent. per annum from the date of said order of said board of county commissioners, is not paid as hereinabove provided, on or before the first Monday in October following the date of said order, the board of county commissioners shall, at the regular meeting for the levy of taxes in the month of October following the date of said order, make an order that the amount of such claim, costs and interest, together with a penalty of six per cent. thereon, shall be a tax on the premises described in said claim and collected as other taxes are collected and said last named amount shall be added to the amount of taxes levied against said premises for current expenses. Upon the making of said order the county auditor shall mark the recorded order of said board fixing the amount of said claim of lien "cancelled and amount hereof charged as taxes against the property." Upon the collection of said tax by the county treasurer the same shall be credited to the current expense fund of the county.

SEc. 15. It shall be unlawful for any person to import into this state, sell, barter, or otherwise dispose of or offer for sale or have in his possession for the purpose of sale or barter any fruit which is or has been infected with peach mildew, peach twig borer, San Jose scale or other

- insect pests or the larvae of the codling moth or peach twig borer, and the fact that any fruit bears the mark of any such scale insect or is worm eaten by any such larvae, shall be conclusive evidence that the fruit is infected, within the meaning of this section: Provided, That nothing in this section shall be construed to prevent the grower of such infected fruit grown within the State of Washington from manufacturing the same into a by-product or selling and shipping the same to a by-product factory.

SEC. 16. It shall be the duty of every person growing or packing and selling, offering for sale or shipping in closed boxes or packages, any fruit grown in this state, to plainly mark the same on the outside of the box or package with the name of the variety contained therein or with the 
words "variety unknown," the name of the place or locality where grown and the name of the grower, or, in case of sale or shipment through an association or organization of growers, the name of such association and the lot number of the grower, and, in case of apples, pears or peaches, the net weight or the number contained in the package, and it shall be unlawful for any person to mark, or place upon, any such package the name of any other place or locality than the place where such fruit was grown, except the place to which shipped, or to falsely mark any such package as to variety, name of grower, association or organization, or place where grown, or to obliterate or change the original marks on any such package or to re-mark the same with the name of any other grower or of any other place than that by or in which the contents were grown, or in case such package is marked with the name of an association or organization of growers to re-mark the same with the name of any other association or organization, and it shall be unlawful for any person having in his possession for sale or offering for sale or selling any fruit grown in this state and shipped in closed packages, to repack the same in the boxes or packages of any other grower or shipper or from any other place, or to sell or offer for sale in closed packages any such fruit except in the original packages, or to pack in or offer for sale. from any marked box or package any fruit other than that originally contained or shipped therein. In addition to the marks required to be placed upon any closed package of fruit grown in this state, as hereinabove provided, the grower thereof or association or organization of growers packing the same, may mark upon the outside of such package the grade of the fruit contained therein either as "First Grade," "Grade No. 1," or "Extra Fancy," "Second Grade," "Grade No. 2," or "Fancy," "Third Grade," "Grade No. 3," or "C Grade," or such other designation as will indicate first, second or third quality of fruit and "Washington Standard Pack" and it shall be unlawful for any person to re-mark any such closed 
package as a higher or superior grade than that originally marked by the grower thereof or association or organization packing the same, or for any person other than the grower or association or organization packing such fruit grown in this state to place upon any such closed package not marked with the grade of the contents thereof any mark or brand indicating the grade of such contents. Provided that nothing in this section shall be construed to apply to canned or dried fruit.

SEc. 17. It shall be unlawful for any grower thereof or association or organization of growers packing apples to mark the package with the grade of the contents unless such contents shall comply with the general rules and regulations made, adopted, issued and published from time to time by the commissioner of agriculture, which general rules and regulations shall define and establish the standard for (1) "First Grade," "Grade No. 1," or "Extra Fancy," (2) "Second Grade," "Grade No. 2," or "Fancy," (3) "Third Grade," "Grade No. 3," or "C Grade," and (4) "Orchard Run," which general rules and regulations shall be adopted, issued and published within thirty days after the taking effect of this act and the commissioner of agriculture is authorized and directed to in the month of December of each year make, adopt, issue and publish general rules and regulations governing the packing of apples and establishing and defining the grades thereof for the ensuing calendar year and in adopting the same the commissioner is authorized to consult and advise with fruit growers, the officers of associations or organizations of apple growers or distributors or dealers in apples. Before making the rules and regulations for which provision is made in this section the commissioner of agriculture shall provide for a public hearing of horticulturists thereon, notice of which shall be given by mail to every horticultural society, growers' association or marketing organization which shall have filed with him a notice of its existence thirty days before the date of any such hearing, and which shall be a resident of the State of 
Washington. For the conducting of such hearing the commissioner of agriculture may prescribe all necessary reasonable rules, but said rules must be such as to insure a fair, full and impartial opportunity for all interested districts to be heard. In establishing the grading rules herein mentioned the commissioner of agriculture shall base them on the necessities and proprieties as shown at said hearing, taking into consideration the tonnage of commercial fruit in each district of the state affected by the grading rules to be established.

SEC. 18. It shall be the duty of every person within forty-eight hours after removing any cuttings or prunings from bacterially infected trees or plants to destroy or disinfect the same by burning or scorching.

SEC. 19. It shall be the duty of the proper state officials, of the board of county commissioners of each county, of the mayor and council or other governing officials of each city and town and of the officers of each irrigation district and school district to, in compliance with the provisions of this act, cause the disinfecting of all infected trees and shrubbery growing upon the public highways, grounds, canals or other public property of such state, county, city, town or district, and such county commissioners and municipal officers are hereby authorized to expend the funds of such county or municipal corporation in carrying out the provisions of this section, and in case of the failure or neglect of any of the aforesaid officers to comply with this section, compliance therewith may be compelled by writ of mandate sued out in a superior court of competent jurisdiction in an action begun in the name of the state upon the relation of the commissioner of agriculture.

SEC. 20. It shall be unlawful for any person, firm or corporation to engage in, conduct or carry on the business of selling, dealing in or importing into this state for sale or distribution, any nursery stock, or to act as agent, salesman or solicitor for any nurseryman or dealer in nursery stock or to solicit orders for the purchase of nursery stock, without first having obtained from the 
commissioner of agriculture and having in force a license so to do, and it shall be unlawful for any person to falsely represent that he is the agent, salesman, solicitor or representative of any nurseryman or dealer in nursery stock. No license shall issue until the applicant therefor shall have paid the fee and furnished the bond, as in this act required. The license fee shall be five dollars for nurserymen and dealers in nursery stock and one dollar for agents, salesmen and solicitors. All licenses shall be in the name of the person, firm or corporation licensed, and shall show the purpose for which issued, the name and location of the nursery or place of business of the nurseryman or dealer licensed or represented by the agent, salesman or solicitor licensed, and no license shall be issued to any agent, salesman or solicitor unless the nurseryman or dealer represented shall be licensed. All licenses shall bear the date of issue and shall expire on the first day of July next following the date of issue: Provided, That all licenses in force at the time of the taking effect of this act shall continue in force during the term for which they were issued, unless sooner revoked, and any holder of such license applying for a license under this act prior to the first day of July next following the expiration of his former license, shall be required to pay therefor only the proportional part of the fee required for an annual license for the remaining portion of the year until the first day of July next following.

SEc. 21. Every nurseryman or dealer in nursery stock, applying for a license under this act shall make, execute and file with the commissioner of agriculture a bond running to the State of Washington, in the sum of one thousand dollars with surety or sureties to be approved by the commissioner, conditioned for the faithful compliance by the applicant with all of the provisions of this act and the laws of the State of Washington relating to the sale, disposition, delivery, inspection and disinfection of nursery stock grown, dealt in, imported, sold, handled or delivered by him during the term of the license applied for and the 
term or terms of any renewal of the same, and conditioned further that all nursery stock sold or delivered by him during said term or terms shall be true to name, age, and variety as represented, and free from the diseases and pests required to be guarded against by this act.

Every licensed nurseryman or dealer in nursery stock who shall have complied with the provisions of this section shall be entitled, upon the expiration of his license or any renewal thereof, by the payment of the fee of five dollars on or before the date of the expiration of his license or any renewal thereof, to have his license renewed for the ensuing year ending July 1st, by the giving of a bond as herein specified.

The cancellation or revocation of, or the withdrawal of the sureties from, any bond filed in accordance with the provisions of this section, shall ipso facto work a suspension of the license of the principal of said bond and the license of all agents, salesmen and solicitors employed by and representing him, until such time as such principal shall furnish a new bond to be approved by the commissioner of agriculture.

SEC. 22. Upon complaint in writing, verified under oath by the complainant, being made to the commissioner of agriculture, that the holder of any license in this act provided for has violated or failed to comply with the provisions of this act or the laws of the State of Washington relating to horticulture, the commissioner, if in his judgment the complaint justifies a hearing thereon, shall serve upon the holder of such license by registered mail, a copy of such complaint and a notice of the time and place of hearing the same, which hearing shall not be less than ten nor more than thirty days from the date of mailing said notice, and shall be at such place to be determined by the commissioner, as shall be most convenient to all the parties to the hearing: Provided, In case the nursery and principal place of business is within this state then hearing shall take place in the county where the nursery or principal place of business is located for the attendance of witnesses. 
The complainant and the person complained of shall have compulsory process to compel the attendance of witnesses at such hearing, to be issued by the commissioner. Hearings may be held by the commissioner in person or by the assistant who shall report in writing a synopsis of the testimony taken and his findings thereon to the commissioner for his decision. If upon such hearing or report it shall appear to the satisfaction of the commissioner that the person complained of has violated or is violating or failing to comply with the provisions of this act or the laws of the State of Washington relating to horticulture, he may revoke the license of such person, and no new license shall issue to such person until it shall be made to appear to the satisfaction of the commissioner that the cause of the complaint has been removed.

From the decision of the commissioner revoking a license, or refusing to issue a new license, an appeal shall lie to the superior court of the county where the hearing shall have been held.

SEc. 23. It shall be unlawful for any person to deceive or defraud any person on the sale of any nursery stock by substituting inferior or different varieties from those ordered, or to wilfully or intentionally bring into this state or to offer for sale or distribution within this state or to ship, sell or deliver upon any sale any nursery stock that is infected, and in case of any such deceit, fraud or substitution, the person, firm, or corporation damaged or injured thereby shall have recourse against the bond filed by the licensed nurseryman or dealer from whom such stock has been purchased, for all damages sustained, which damages may be recovered at the suit of the party injured against the nurseryman or dealer causing the damage and the sureties on such bond in any court of competent jurisdiction.

SEc. 24. It shall be the duty of all nurserymen and dealers in nursery stock and all salesmen, solicitors and agents therefor to give to every person ordering any nursery stock a duplicate copy of such order which shall 
show: (a) the name of the nurseryman from whom ordered and the name of the solicitor, salesman or agent taking such order: (b) the season of the order and the date when delivery is to be made: and, (c) the number, name, and price of each variety of tree or plant ordered.

SEC. 25. It shall be the duty of every person growing or dealing in nursery stock to notify the commissioner of agriculture of his, their or its intention to ship any nursery stock from one point in this state to another or from any point without the state to a point within the state for sale or delivery or for planting or propagation. Such notice shall be made in writing and in duplicate and signed by the person giving the notice and shall show the name and address of both the consignor and consignee, and the name of the person or transportation company from whom the consignee is to receive such goods, and whether such nursery stock has been inspected and approved at the initial point of shipment within this state by an horticultural inspector. Said notice shall be mailed not later than the date of shipment and the duplicate thereof shall be mailed to the horticultural inspector stationed nearest to the point of consignment and all such shipments of nursery stock shall be plainly marked on the outside of the package with the words "nursery stock." A descriptive invoice of all goods shipped during the season shall be mailed to the commissioner of agriculture before the first of July following shipment.

SEC. 26. In the event of the shipment into this state from any point without this state of any nursery stock by a person, firm or corporation not licensed to do business in this state as in this act provided, it shall be the duty of the purchaser or person receiving such nursery stock to have the same inspected by a horticultural inspector in the same manner as is required upon the delivery of nursery stock sold and delivered by a licensed nurseryman or dealer in nursery stock within this state and to pay an inspector's fee of ten per cent. of the invoice price of such shipment, provided that the minimum fee for such inspection shall 
be fifty cents and the actual and necessary traveling expense of the inspector making the inspection: And provided further, That for the inspection of shipments of nursery stock shipped to nurserymen or dealers in nursery stock licensed under the provisions of this act to do business in this state, no fee shall be required.

SEc. 2\%. Upon the arrival at its point of destination of any nursery stock shipped into this state from another state or country or shipped from one point within this state to another, it shall be the duty of the freight agent, express agent or the agent of the persons or transportation company having such shipment in charge for delivery, unless the same is accompanied by a certificate of inspection and approval by a horticultural inspector of this state showing that the same was inspected and approved at the initial point of shipment within this state, to notify the horticultural inspector stationed nearest to the point where said shipment is received, of the receipt of such shipment giving the name of the consignor and consignee and stating that such shipment is ready for inspection and delivery. Said notification may be by telephone or telegraph, or by written notice delivered personally to said inspector or to some person of suitable age and discretion at his residence or office, or by mail addressed to said inspector at his place of residence or at his office; and it shall beunlawfulfor any such agent or person having such shipment in charge to deliver the same to the consignee or to any other person until the same shall have been inspected by a horticultural inspector: Provided, however, That such agent shall not be required to hold such shipment more than forty-eight hours after notifying the inspector as aforesaid, except in case the notice is given by mail, in which event such shipment shall be held for such period beyond said forty-eight hours as is ordinarily required for the delivery of mail to the address of said inspector; And provided further, That no inspection at the point of delivery shall be necessary if the shipment is accompanied by a certificate of a horticultural inspector of this state showing inspection and ap- 
proval at the initial point of shipment within this state as aforesaid, and upon the delivery of such shipment to the consignee, the agent or person making the delivery shall deliver such certificate of inspection to the consignee and retain the duplicate to show his authority for making delivery without inspection. Any nurseryman or dealer in nursery stock within this state may demand the services of an inspector at his place of business or point of shipment during the shipping season by paying four dollars per day for his services.

Upon the arrival at its point of destination of any shipment of fruit or vegetables shipped into this state from another state or country, it shall be the duty of the freight agent, express agent or agent or persons or transportation company having such shipment in charge for delivery, to notify the horticultural inspector stationed nearest to the point where said shipment is received, of the receipt of such shipment giving the names of the consignor and consignee, and upon the delivery of such shipment to the consignee or his order, the agent or person making such delivery shall demand and receive from the person to whom such shipment is delivered a receipt therefor showing the name and address of the consignee or his order and the place to which said shipment is to be removed, and shall thereupon mail said receipt to the horticultural inspector stationed nearest to the point where said shipment is received.

SEc. 28. No inspection of shipments of nursery stock as provided in the last preceding section shall be made until all transportation charges thereon have been paid: Provided, however, That the agent or person having such shipment in charge for delivery may waive in writing the payment of such transportation charges prior to inspection, and in case the transportation charges are not paid or waived such shipment shall be held until the same are paid and inspection had.

SEc. 29. It shall be the duty of every horticultural inspector upon the inspection of any nursery stock found 
free from diseases and pests, to deliver to the owner or person in charge thereof a certificate of inspection over his signature, showing the date of inspection and stating that such nursery stock was not infected, which certificate, in case inspection be made at the initial point of shipment, shall be in duplicate, and it shall be unlawful for any person to substitute for any such nursery stock so inspected and approved, any other nursery stock not covered by said certificate, or to ship, sell or dispose of any other nursery stock than that actually inspected and approved, under such certificate of inspection, provided that the inspector may issue certificates of general inspection for shipment to points within this state in addition to the regular certificates of inspection.

SEc. 30. Every person violating or failing to comply with the provisions of this act shall be deemed guilty of a misdemeanor and upon conviction thereof shall be fined in any sum not less than $\$ 25.00$. All fines imposed under the provisions of this act shall, when collected, be paid to the treasurer of the county where imposed and remitted to the state treasurer and placed to the credit of the general fund.

SEc. 31. Whenever any person is about to or threatens to violate any provision of this act, the commissioner of agriculture may, with the advice of the prosecuting attorney of the county where such violation is threatened or of the attorney general, begin an action in the superior court of such county in the name of the state upon the relation of such commissioner to restrain and enjoin such threatened violation, and in case such prosecuting attorney shall fail or refuse to begin such action upon the request of the commissioner, the same may be begun by or under the direction of the attorney general. In such action no bond shall be required for the issuance of a restraining order or injunction, but the state shall be liable for any damages occasioned by the unlawful suing out of such restraining order or injunction. 
SEC. 32. The commissioner of agriculture, the assistant commissioner and all horticultural inspectors are hereby authorized and empowered to seize and hold for use as evidence any article or thing found in the possession of or used, held for shipment, shipped, offered for sale or sold by any person in violation of any of the provisions of this act or of any law relating to horticulture, and to serve and enforce compliance with any restraining order or writ of injunction or mandate or any other writ issued by any court under the provisions of this act.

SEc. 33. It shall be the duty of all clerks, bookkeepers, express agents, railroad officials, employees, or employees of common carriers to render to the commissioner of agriculture and his inspectors all the assistance in their power in tracing, finding, or discovering the presence of any article named in this act. Any refusal or neglect on the part of such clerks, bookkeepers, express agents, railroad officials, employees, or employees of common carriers to render such friendly aid to assist in the carrying out of the provisions of this act shall constitute a misdemeanor.

SEC. 34. That all acts incorporated and enumerated in the following schedule, and all acts and parts of acts in conflict with the provisions hereof, are hereby repealed.

SCHEDULE.

Sections $3075,3079,3080,3083$, to 3110 , inclusive; $3113,3115,3116,311 \%, 3119,3120,3122$ to $312 \%$, inclusive; 3131 and 3134 to 3139 , inclusive of Remington and Ballinger's Annotated Codes and Statutes of Washington.

SEC. 35. This act is necessary for the immediate preservation of the public peace, health, and safety and shall take effect immediately.

Passed the House March 1, 1915.

Passed the Senate March 8, 1915.

Approved by the Governor March 19, 1915. 